\title{
A Review of the Diversity of the Genital Tract Microbiome and Implications for Fertility of Cattle
}

\author{
Mounir Adnane ${ }^{1, *(\mathbb{D})}$ and Aspinas Chapwanya ${ }^{2}$ \\ 1 Institute of Veterinary Sciences, University of Tiaret, Tiaret 14000, Algeria \\ 2 Department of Clinical Sciences, Ross University School of Veterinary Medicine, West Indies, \\ Basseterre 00265, Saint Kitts and Nevis; achapwanya@rossvet.edu.kn \\ * Correspondence: mounir_vet@yahoo.fr; Tel.: +21-3542-477061
}

Citation: Adnane, M.; Chapwanya, A. A Review of the Diversity of the Genital Tract Microbiome and Implications for Fertility of Cattle. Animals 2022, 12, 460. https:/ / doi.org/10.3390/ani12040460

Academic Editor: Alessandro Ricci

Received: 6 January 2022

Accepted: 31 January 2022

Published: 13 February 2022

Publisher's Note: MDPI stays neutral with regard to jurisdictional claims in published maps and institutional affiliations.

Copyright: (C) 2022 by the authors. Licensee MDPI, Basel, Switzerland. This article is an open access article distributed under the terms and conditions of the Creative Commons Attribution (CC BY) license (https:// creativecommons.org/licenses/by/ $4.0 /)$.
Simple Summary: Reproductive systems of cattle contain multiple microbes resident in the female from a young age. Sometimes other harmful microbes can invade the genital tract and cause diseases that impair fertility. Normally, commensal microbes facilitate genital tract homeostasis and produce factors that stimulate male sexual response. For this reason, the type and number of microbes present in the genital tract are important for reproductive tract health, and any disruption of this microbial balance leads to genital diseases. Interestingly, these microbes frequently populate the genital tract of cows, leading to reproductive diseases that perturb fertility. However, a microbiome composed of commensal microbes will likely result in the restoration of uterine health and improved fertility of the cows.

Abstract: Cattle have a genital microbiome that is established early in life, even before calving. Microbial influx into the reproductive system of cows, during calving or mating, is unavoidable and is likely to alter the commensal microflora composition. It is now well established that a commensal endometrial flora is largely responsible for the overall fertility of cows. These microbes are important for maintenance of structural integrity of the genital mucosal barrier, immunomodulation, and protection against pathogens. Further, the genital microbiome functions in the semiochemical communication between a male and female. An optimal balance between the abundance and diversity of the microbiome is essential to promote female genital tract health. Disruption of this balance leads to dysbiosis and genital diseases and perturbed fertility. As part of the global strategy of One World, One Health, there is a need to reduce antibiotic use in animals. This area of research has the potential to expand the knowledge about the nexus between the endometrial microbiome and fertility including being probiotic in different species.

Keywords: genital; microbiome; health; cattle; pathogens

\section{Introduction}

The term microbiota refers to the entire population of microorganisms that colonizes a particular location and includes not just bacteria, but also other microbes such as fungi, archaea, viruses, and protozoans [1]. Cows have bacteria inhabiting the uterus even before calving and establish a unique endometrial microbiome within 20 min of calving where the microbiome is similar between cows that develop metritis and cows without endometritis until at least the second day postpartum. The microbiome of cows that develop metritis has higher relative abundance of Bacteroidetes and Fusobacteria and lower relative abundance of Proteobacteria and Tenericutes [2]. Furthermore, a mixture of bacteria, protozoa, fungi, and viruses is present in the genital tract of different species, including cattle [3]. While uterine infection is, in general, caused by mixed bacterial infections, the main microbial pathogens involved include Trueperella pyogenes (T. pyogenes), Fusobacterium necrophorum (F. necrophorum), Bacteroides spp., and Prevotella spp. [4,5]. Microbial populations of the 
genital tract are highly variable, and Lactobacillus and Bacteroides are the most predominant in vaginal flora of women and cows, respectively [6,7]. The uterus has a unique microbiome, especially during pregnancy when the cervical contents are isolated from the vaginal contents as a result of the cervical mucus plug that is present during this period [8].

Significant interest has evolved for the genital tract microbiota in recent years within the scientific community such that the genital microbiota is thought to be associated with infertility or uterine diseases. The genital microbiome has important functions in the female reproductive tract through differential microbial competition. Symbiotic microorganisms create a biofilm that complements the cervicovaginal mucus, thereby protecting the genital tract from invasion by pathogens $[9,10]$. Furthermore, commensal microbes produce bioactive molecules such as lactic acid and reactive oxygen species that inhibit proliferation of pathogens [11]. During pregnancy, some Lactobacilli species confer protection of the offspring and are also associated with normal delivery [12]. Some recent studies focused on other aspects of reproductive function of cattle influenced by the genital microbiome such as pheromone production and semiochemical signaling [13].

While the genital microbes are thought to originate from the environment or different organs such as the rumen, skin, rectum or feces, the vagina is considered to be the main source of endometrial microfauna, especially during the times when the cervical lumen is less restricted at estrus, breeding or parturition (Figure 1) [8]. Vaginal mucus is less viscous during these time periods, allowing the uterus to be colonized by various bacteria, fungi, viruses, and protozoans of vaginal origin [3]. It is noteworthy that microbes can also access the genital tract hematogenously [14]. During calving, microbes prevalent in the environment influx into the uterus of cows. From an immunological perspective, these microorganisms are recognized as being pathogenic by the host immune defense system, thereby inducing a response to eliminate the pathogens. Typically, in cattle there is activation of the host defense system for removal the bacteria during endometrial involution within the first five weeks after calving [15]. It seems that the genital microbiome diversity is affected by many factors, some of, which are specific to the female such as estrous cyclicity [16] and pregnancy [17]. However, extrinsic factors such as nutrition [18] and genital pathologies [16,19] are equally important. The majority of the genital tract bacteria are non-pathogenic and are present with the enterocytes in a symbiotic relationship.

In humans, alteration of normal microbial diversity can lead to dysbiosis, infertility [20] or genital diseases such as vulvovaginal candidiasis [21]. There have been some studies conducted in animals on dysbiosis of the genital tract $[17,22]$. In this review paper, the focus was on the genital microbiome in cattle and how it has similarities to the human microbiome that has been extensively interrogated in relation to genital infections and infertility. While this paper is not a systematic review, there was a search and selection of all possible and recently published papers with relevant information and in direct relation to the topics of this paper. Because the microbiome has been investigated to a greater extent in humans, it was useful to include findings from some papers in this review with the most relevant results that can be applied in the animal field. In this review, we focus on the origin, diversity, and clinical relevance of microbiota and the risk for uterine disease or infertility of cattle. We also explore how this information can inform strategies such as proand prebiotics in combating uterine diseases. 


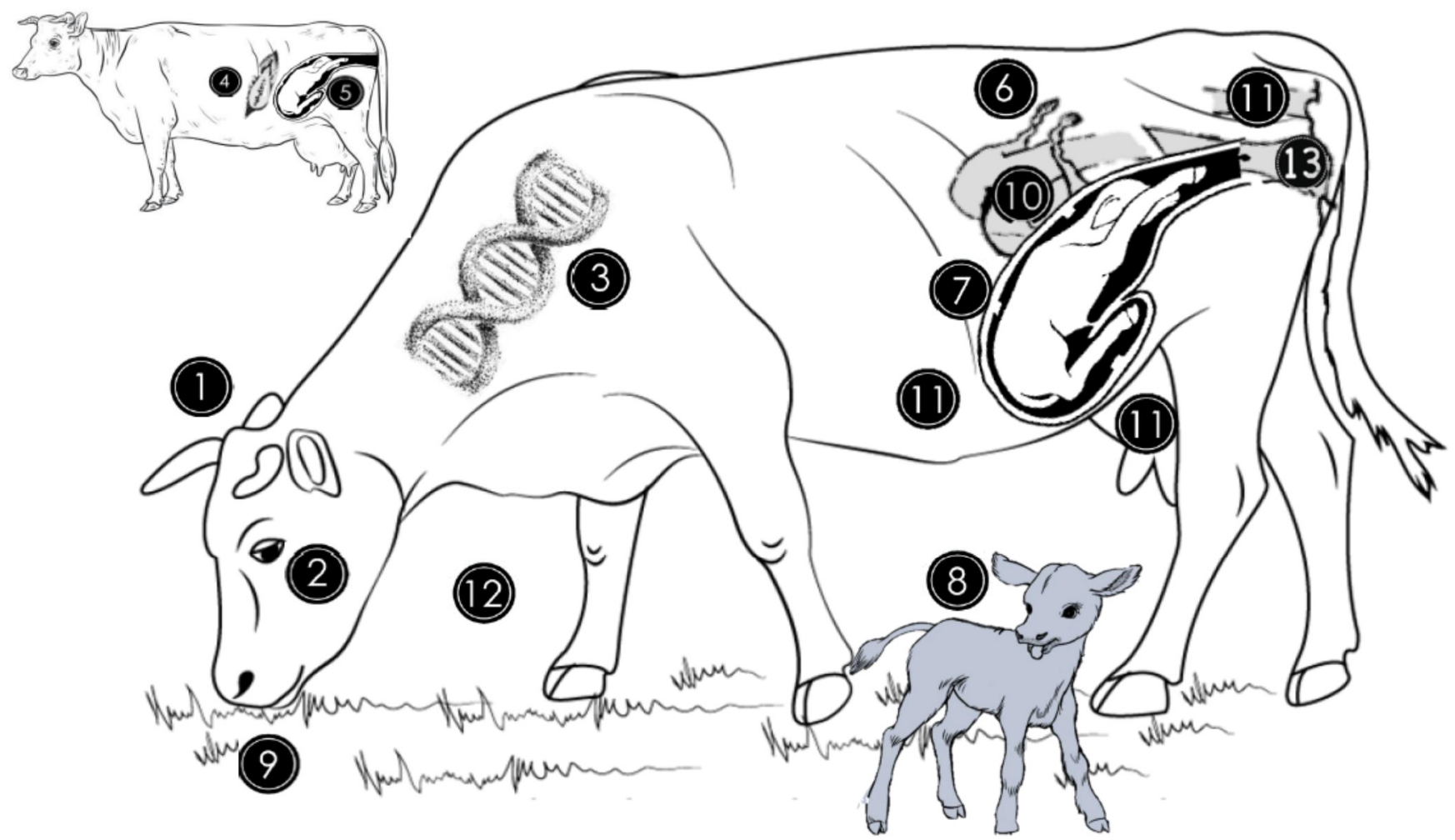

Figure 1. Origin of genital microbiome and factors that can affect the abundance and diversity of the microbial population. The genital microbiome is highly variable between species (1) and individuals of the same species (2). For instance, in cattle, genital microbiota is different between Gyr, Nellore, and Holstein breeds (3). The general microbiome of the newborn is similar to the mother's skin microbiome if the delivery method was caesarean section (4) and is similar to the vaginal microbiome if it was natural delivery (5). Estrogen and progesterone hormone concentration variations during the estrous cycle influence bacterial growth in the genitalia by favoring some species at different times (6). During pregnancy, bacterial quantity and diversity decrease while archaeal abundance increases in vaginal milieu (7). Vaginal and uterine microbiomes of cows not diagnosed with metritis during the first month postpartum are similar in cows without uterine infections but differ from those with uterine infections (8). Dietary quality and quantity peripartum alter the endometrial microbiome through the provision of energy and protein nutrients (9). The uterine microbiome between 10 and 35 days postpartum is similar in cows not diagnosed with subclinical endometritis and those that will develop subclinical endometritis (10). Rumen, skin, rectum or feces (11) contribute to the establishment of the genital microbiome, while the environment (12) and intravaginal antibiotic therapy (13) can also alter the endometrial microbiota during a female's lifetime.

\section{The Genital Tract Contains a Dynamic Microbiota}

The traditional dogma is that the endometrial environment is sterile, particularly during pregnancy [23]. It is now known that during calving, microbes present in calving areas can gain access to the uterus of the cow [24,25]. To identify the invading bacterial species, laboratories routinely utilize culture-based microbiological assays [26]. The advent and rapidly growing interest and availability of gene sequencing techniques mean that microbiome data using broad evaluation approaches are now readily available. Findings when using the independent culture methods of sequencing are revealing that the uterus of cattle contains a dynamic microflora $[8,26,27]$. Even during pregnancy, when the cervical plug is present, resulting in an isolation of the vaginal from the uterine microbiome, the uterus of cattle contains a unique microbiome during gestation [26]. The breakthrough findings that the human neonate is exposed to diverse bacterial species, originating from different sources depending on the type of delivery, paved the way for new discoveries in animals [28]. 
In cattle and sheep, Bacteroidetes, Fusobacteria, and Proteobacteria are the most common phyla in the genital tract [10]. At the genera level, Aggregatibacter spp., and Streptobacillus spp. were the most abundant. Interestingly, Lactobacillus spp., the predominate microbial populations in the human genital tract, were present in $80 \%$ and $90 \%$ of vaginal samples from ewes and cows, respectively [7,10,29]. In women, where the genital microbiome is intensively investigated, there are different vaginal microbial community state types (CSTs). The CSTs are defined by the dominant Lactobacillus species; CST I: Lactobacillus crispatus (L. crispatus), CST II: L. gasseri, CST III: L. iners, and CST V: L. jensenni. The CST IV population is defined by the absence of Lactobacilli species and the large diversity with strict and facultative anaerobic bacteria [7]. Such groupings, if present in cattle, may be indicative of bacterial profiles beneficial for fertility.

\section{Significance of the Genital Microbiome}

The reproductive tract microbiome of cattle is relatively under-explored, particularly in terms of the specific taxonomic classification and functional aspect of the microbiome, which are beneficial for the development of diagnostic methods, such as microbial biomarkers and dysbiosis indexes. The genital microbes in humans and animals have protective functions against major pathogens. In women, Lactobacilli produces lactic acid, which regulates vaginal $\mathrm{pH}$ and inhibits the proliferation of pathogens [30]. In turn, symbiotic bacteria utilize the secretions of the genital tract such as mucus sugar and proteins as a source of essential nutrients [11]. Lactic acid also induces acidification of milieu within the vagina, which interferes with intracellular functions, leading to microbial elimination [31]. Results from in vitro studies revealed that Chlamydia trachomatis is inactivated when there are normal concentrations of lactic acid [32], as are Neisseria gonorrhoeae and Escherichia coli (E. coli) $[33,34]$. One of the potential benefits of the commensal bacteria in women is the protection against human immunodeficiency virus type 1 (HIV-1). It seems that Lactobacilli in the vagina protect women from contracting HIV-1 during sexual intercourse. Lactic acid and the resultant biofilm limit the number of free virions and thereby reduce the shedding of HIV [35,36]. In vitro, HIV-1 is irreversibly inactivated when challenged with normal concentrations of lactic acid [37]. This may be the mechanism by which Lactobacilli confers vaginal protection against pathogens.

The genital microbiome is also implicated in the sociochemical signaling in different species through the production of pheromones $[13,38,39]$. Pheromones are produced by the microbiome by either direct production of pheromonal cues or through the fermentation hypothesis, by which microbes metabolize existing endogenous organic compounds to produce highly volatile compounds [40]. Results from a study in buffalo indicated there was a repetitive Flehmen response of males exposed to vaginal mucus from females at estrus [41]. Interestingly, the pheromones elaborated vary with the diversity of the genital microbiome $[13,42]$.

\section{Origin of the Genital Microbiome}

The composition of the neonate microbiome is determined by the mode of birth and environment [28]. In humans, the general microbiome of the neonate delivered vaginally is similar to the maternal vaginal microbiome, dominated by Lactobacillus, Prevotella, or Sneathia spp. Neonates delivered through caesarean-section have a general microbiome similar to the maternal skin microbiome, mainly composed of Staphylococcus, Corynebacterium, and Propionibacterium spp. [28] (Figure 1). Therefore, initial exposure to the maternal microbiome influences an individual's microbial load and diversity [28,43]. In cattle, microbes such Bacteroides and Enterobacteriaceae present in the genital tract causing reproductive diseases are thought to originate from the gut or the environment [44,45]. The results from some studies suggested that the vaginal microbiome originates from the gastrointestinal system [46], whereas others concluded that the vaginal microbial population includes methanogen species, and therefore the vaginal microbiome contributes to the establishment 
of the digestive tract microbiota [17]. The hematogenous route is also an important possible route for uterine contamination with pathogens [8].

\section{Diversity of the Genital Microbiome}

\subsection{Vagina}

Cows without uterine infections have in the vagina 15 taxa, predominantly Bacteroides (28.3\%) and Enterobacteriaceae (17.8\%), in addition to Victivallis (7.2\%), Streptococcus (6.1\%), Phyromonadaceae (5\%), Alistipes (3.9\%), Coriobacteriaceae (3.3\%), Clostridium (3.3\%), Betaproteobacteria (2.8\%), Corynebacterineae (2.8\%), Cytophagaceae (2.8\%), Oscillibacter (2.8\%), and Planctomycetaceae (2.8\%) [6]. Cows with reproductive diseases such as purulent vaginal discharge have a more diverse vaginal microbiome containing 68 taxa, dominated by Bacteroides (35.83\%), Enterobacteriaceae (18.62\%), Histophilus (8.79\%), Alistipes (4.34\%), Flavobacteriaceae $(1.77 \%)$, Victivallis $(8.49 \%)$, Coriobacteriaceae $(2.44 \%)$, Streptococcus $(2.09 \%)$, Barnesiella (2.03\%), and Oscillibacter (1.24\%) (Table 1) [6]. Results from another study indicated that unclassified Enterobacteriaceae (21.05\%), Ureaplasma (4.37\%), and unclassified Bacteroidaceae (2.49\%) were the most predominant [17]. At the phyla level, Tenericutes (36\%), Proteobacteria (30\%), Fusobacteria (7.6\%), and Firmicutes $(1.8 \%)$ were the most abundant [47]. In the study by Deng et al. (2019), Firmicutes (31.57\%), Proteobacteria $(24.08 \%)$, Bacteroidetes $(12.96 \%)$, and Tenericutes (4.95\%) were the most prevalent in the vagina. A comparison of the results from these two recent studies reveals that the proportions of the predominant microbial populations differ significantly between individuals.

Table 1. Richness and diversity of the vaginal microbiome in cattle.

\begin{tabular}{|c|c|c|c|}
\hline & Factors & Genital Microbiome Composition & References \\
\hline Species & Bos taurus & $\begin{array}{c}\text { Phylum: Proteobacteria, Fusobacteria, and Bacteroidetes. } \\
\text { Genera: Aggregatibacter spp., and Streptobacillus spp. } \\
\text { Lactobacilli, Sneathia spp., Porphyromonas spp., and } \\
\text { Prevotella spp. }\end{array}$ & {$[7,10]$} \\
\hline \multirow{3}{*}{ Breed } & Holstein & $\begin{array}{c}\text { Phylum: Firmicutes, Tenericutes, Proteobacteria, and } \\
\text { Bacteriodetes Actinobacteria and Spirochaetae }\end{array}$ & {$[48]$} \\
\hline & Gyr & $\begin{array}{c}\text { Bacteria genus: Firmicutes, Bacteroidetes, Proteobacteria, } \\
\text { and Actinobacteria } \\
\text { Fungal genus: Mycosphaerella and Cladosporium. } \\
\text { Archaea genus: Methanobrevibacter genus. }\end{array}$ & [49] \\
\hline & Nellore & $\begin{array}{l}\text { Bacteria: Firmicutes, Bacteroidetes, Proteobacteria, and up } \\
\text { to } 20 \% \text { of the unclassified bacteria fungal genus: } \\
\text { Mycosphaerella and Archaeal genus: Methanobrevibacter }\end{array}$ & [46] \\
\hline \multirow{3}{*}{ Estrous cyclicity } & Follicular phase (high estradiol) & Pasteurellaceae unclassified & [47] \\
\hline & \multirow[b]{2}{*}{ Luteal phase (Low estradiol) } & Larger microbial diversity & {$[46,47,50]$} \\
\hline & & $\begin{array}{l}\text { Bacteroidete spp., Histophilus somni, Actinobacillus } \\
\text { seminis, and unclassified Fusobacterium }\end{array}$ & [47] \\
\hline \multirow{6}{*}{ Pregnancy } & \multirow[t]{2}{*}{ Pregnant } & $\begin{array}{l}\text { Microbiome is relatively stable throughout the } \\
\text { gestational period }\end{array}$ & [17] \\
\hline & & Pasteurella multocida & [47] \\
\hline & \multirow[b]{2}{*}{ Non pregnant } & Pasteurellaceae spp. Fusobacterium spp. & [47] \\
\hline & & $\begin{array}{l}\text { Histophilus somni, Clostridiaceae 02d06, } \\
\text { and Campylobacter }\end{array}$ & [17] \\
\hline & \multirow{2}{*}{ Abortion } & Staphylococcus aureus & [51] \\
\hline & & Trueperella pyogenes & [52] \\
\hline
\end{tabular}


Table 1. Cont.

\begin{tabular}{|c|c|c|c|}
\hline & Factors & Genital Microbiome Composition & References \\
\hline \multirow{2}{*}{ Postpartum } & First 35 days postpartum & $\begin{array}{c}\text { Porphyromonas, Bacillus, Schlegelella, Paracoccus, } \\
\text { and Fusobacterium }\end{array}$ & [53] \\
\hline & First 50 days postpartum & $\begin{array}{l}\text { Similar between individuals } \\
\text { Enriched with Firmicutes }\end{array}$ & {$[54]$} \\
\hline \multirow{13}{*}{ Uterine disease } & \multirow{4}{*}{ Without uterine disease } & $\begin{array}{c}\text { Bacteroides }(28.3 \%), \text { Enterobacteriaceae }(17.8 \%) \text {, Victivallis } \\
(7.2 \%), \text { Streptococcus }(6.1 \%), \text { Phyromonadaceae }(5 \%), \\
\text { Alistipes }(3.9 \%) \text {, Coriobacteriaceae }(3.3 \%) \text {, Clostridium } \\
(3.3 \%), \text { Betaproteobacteria }(2.8 \%), \text { Corynebacterineae } \\
(2.8 \%), \text { Cytophagaceae }(2.8 \%), \text { Oscillibacter }(2.8 \%) \text {, and } \\
\text { Planctomycetaceae }(2.8 \%)\end{array}$ & [6] \\
\hline & & $\begin{array}{c}\text { Unclassified Enterobacteriaceae }(21.05 \%) \text {, Ureaplasma } \\
(4.37 \%) \text {, and unclassified Bacteroidaceae }(2.49 \%) \\
\text { Firmicutes }(31.57 \%) \text {, Proteobacteria }(24.08 \%), \\
\text { Bacteroidetes }(12.96 \%) \text {, and Tenericutes }(4.95 \%)\end{array}$ & [17] \\
\hline & & $\begin{array}{c}\text { Phylum: Tenericutes (36\%), Proteobacteria }(30 \%), \\
\text { Fusobacteria }(7.6 \%) \text {, and Firmicutes }(1.8 \%)\end{array}$ & [47]. \\
\hline & & Firmicutes are the most predominant & [54]. \\
\hline & \multirow[t]{3}{*}{ With uterine diseases (all included) } & $\begin{array}{c}\text { Bacteroides }(35.83 \%), \text { Enterobacteriaceae }(18.62 \%), \\
\text { Histophilus }(8.79 \%), \text { Alistipes }(4.34 \%), \text { Flavobacteriaceae } \\
(1.77 \%), \text { Victivallis }(8.49 \%), \text { Coriobacteriaceae }(2.44 \%), \\
\text { Streptococcus }(2.09 \%), \text { Barnesiella }(2.03 \%) \text {, and } \\
\text { Oscillibacter }(1.24 \%)\end{array}$ & [6] \\
\hline & & Small Firmicutes to Bacteroidetes ratio & \multirow{2}{*}{ [54] } \\
\hline & & $\begin{array}{l}\text { Enriched with Bacteroides, Helcococcus, } \\
\text { and Fusobacterium }\end{array}$ & \\
\hline & \multirow{3}{*}{ Metritis } & $\begin{array}{l}\text { Lower microbial diversity } \\
\text { Higher relative abundance of Bacteroides, } \\
\text { Porphyromonas, and Fusobacterium }\end{array}$ & {$[8,55]$} \\
\hline & & $\begin{array}{l}\text { Enriched with Fusobacterium necrophorum, } \\
\text { Porphyromonas levii, and Prevotella melaninogenica }\end{array}$ & [56] \\
\hline & & Enriched with Escherichia coli & {$[8,57]$} \\
\hline & Clinical endometritis & $\begin{array}{c}\text { Lower bacterial diversity } \\
\text { High prevalence of Fusobacterium and Trueperella } \\
\text { Lower abundance of Escherichia, Shigella, Lactobacillus, } \\
\text { Prevotella, Schlegelella, and Streptococcus }\end{array}$ & {$[53,54]$} \\
\hline & Subclinical endometritis & $\begin{array}{l}\text { Greater prevalence of Anaerococcus, Corynebacterium, } \\
\text { and Staphylococcus }\end{array}$ & {$[53,54]$} \\
\hline & Necrotic vulvovaginitis & $\begin{array}{l}\text { Decreased microbial diversity } \\
\text { Large abundance of Bacateroidetes }\end{array}$ & [58] \\
\hline Nutrition & Energy deficiency around calving & High prevalence of Bacteroidetes and Fusobacteria & [18] \\
\hline
\end{tabular}

\subsection{Uterus}

It is now known that cows have a natural microbiome in the uterus during the gestational period $[26,59]$. While the uterine microbes originate mainly from the vagina, and to a lesser extent, from the skin and gut, this microbiome is not as diverse as the vaginal microbiome [60]. Bacteria are always present in the uterus. F. necrophorum, Porphyromonas Levii, and T. pyogenes were detected in pregnant cows [26]. Interestingly, opportunistic microbes, such as Histophilus and Mycoplasmataceae, can become pathogenic [61,62]. Furthermore, the bacterial abundance in the uterus before calving is not associated with inflammation, which is indicative of a greater microbial tolerance during gestation [8]. 


\section{Factors Affecting Genital Microbiome Diversity}

The genital microbiome changes during the lifetime of females. Microbial populations in the reproductive tracts of animals are naturally selected because of different symbiotic functions. For example, in women, Lactobacilli use their small membrane extensions (i.e., fimbriae) that adhere to the genital mucosa [63]. Likewise, the vaginal tissue is rich in collagen, a valuable source of nutrients for Aggregatibacter spp. [9,64]. There are also other factors that affect the genital microbial diversity with some being specific to the stage of the female reproductive cycle, and others are extrinsic such as nutrition. Interestingly, the vaginal microbiome could have originated from the intestinal microbiota from an evolutionary perspective because there are marked similarities between the microbial population of the two anatomical parts [46]. The thought was that this microbial similarity is due to the fact that the vagina and anus are juxtaposed, and feces are often in contact with vulva [46]. However, our prevailing thoughts at present are that the genital microbiome of the neonate initially originated from maternal tissue that is in contact with the neonate subsequent to parturition, as described previously in this review article. The genital microbiome subsequently undergoes several changes during the lifetime of a female under the effect of the many factors, including the contamination by the microbiome of proximate organs such as the gastro-intestinal tract. Recent findings support our hypothesis (Figure 1) [17]. When there was a comparison of the changes in the microbial population in feces and vaginal samples collected before mating and at different stages of the gestational period, the fecal microbial diversity was the same, but the vaginal microbiome changed dynamically at different stages of the gestational period.

\subsection{Intrinsic Factors}

Individual variation in microbial species in the genital tract of bovids is thought to have effects of fertility outcomes [46]. This variation may explain how some animals develop resistance and others become infected with uterine diseases. Such differences are thought to be common in other mammals including humans (Figure 1) [1].

\subsubsection{Species}

The genital microbiome is diverse among animal species and also individual animals, which perturbs the regulation of reproductive hormones (Figure 1) [10]. For example, in two separate studies using either cows with endometritis or those administrated bacterial lipopolysaccharide (LPS), estradiol concentrations were lower, and there was a relatively prolonged period to the time of ovulation during the follicular phase of the reproductive cycle $[65,66]$. The vaginal microbiomes of cattle were composed of a large abundance of Enterococcus spp., Staphylococcus spp., and Streptococcus spp., which was different from the vaginal microbiome of ewes where there was a predominance of Bacillus spp., Corynebacterium spp., Escherichia spp., Staphylococcus spp., and Streptococcus spp. (Table 1) [50,67-69]. At the phyla level, the genital microbiomes in both cows and ewes were composed predominantly of Proteobacteria, Fusobacteria, and Bacteroidetes. At the genera level, Aggregatibacter spp. and Streptobacillus spp. were the predominant species [10]. While Lactobacilli are detected in $80 \%$ of ewes and $90 \%$ of cows, the total microbial population is less abundant, leading to the near-neutral vaginal environment compared to the acid environment in women where there is a large population of Lactobacilli [10]. In addition to Lactobacilli, cows and ewes share several genera, mainly Sneathia spp., Porphyromonas spp., and Prevotella spp. [7,10]. A small Firmicutes to Bacteroidetes ratio is an early indicator of cows that subsequently develop postpartum endometritis [54].

\subsubsection{Breed (Genetic Background)}

In Gyr cattle, a common dairy breed in South American countries such as Brazil, the vaginal microbiome is enriched with bacteria and fungi while there is a small population of archaea (Figure 1) [49]. Among bacteria, Firmicutes, Bacteroidetes, Proteobacteria, and Actinobacteria were the most frequently detected. Mycosphaerella and Cladosporium were 
the most frequently detected fungal genera. While archaea were in low abundance, the Methanobrevibacter genus was the most abundant (Table 1). In Nellore beef cattle, the vaginal microbiome is predominately composed of Firmicutes, Bacteroidetes, Proteobacteria, and up to $20 \%$ of unclassified bacteria [46]. Mycosphaerella was the most abundant fungal genus while Methanobrevibacter was the predominant archaeal genus. In Holstein Friesian cattle, the most ubiquitous dairy breed in North Africa, Europe, and the USA, the vaginal microbiome was predominately composed of Firmicutes, Tenericutes, Proteobacteria, and Bacteriodetes phyla. Other bacteria were detected in smaller quantities such as Actinobacteria and Spirochaetae [48].

\subsubsection{Delivery Mode}

The type of fetal delivery at parturition is one of the major factors affecting the genital microbiome diversity [28]. The general microbiome of the neonate is similar to the maternal skin microbiome if the parturition was by cesarean section and similar to the vaginal microbiome if it was natural delivery (Figure 1) [28]. Early established bacterial communities provide protection against pathogenic bacteria that may be infective agents to the neonate. While the maternal vagina is the main source for the natural microbiome, a unique neonatal microbiome is established shortly after parturition with microbes from other sources. For example, neonates delivered by caesarean section have a greater prevalence of methicillinresistant Staphylococcus aureus (S. aureus) (MRSA) skin infections (64-82\%) compared to when neonates are born without complications (i.e., natural delivery) [28].

\subsubsection{Estrous Cyclicity}

Estrous cycles in cattle are regulated by hormonal concentration changes with relatively higher concentrations of estradiol during proestrus and estrus and relatively higher progesterone concentrations during metestrus and diestrus, having marked effects on the vaginal $\mathrm{pH}$ in mammals [70,71]. Microbes are very sensitive to acidic milieu; therefore, it is thought that when there are greater estradiol concentrations, there will be effects on the microbiome in the genital milieu of some species, with effects varying as a result of estradiol concentrations (Figure 1). Results from a recent study indicated that Bacteroidete spp., Histophilus somni, Actinobacillus seminist, and unclassified Fusobacterium populations increase when there are relatively lower estradiol concentrations in the vaginal milieu (Table 1) [47]. When there are relatively higher estradiol concentrations in the vaginal milieu, unclassified Pasteurellaceae are the predominant microbes in the vagina. Likewise, when there are higher progesterone concentrations, the populations of microbes in the vagina are relatively larger [46,50].

\subsubsection{Pregnancy}

During the gestational period, there is lower microbial diversity of the vaginal microbiome and a greater archaeal population [46]. The bacterial species present in the vagina during the gestational period are less diverse due to the relatively higher progesterone concentrations that lead to suppression of the vaginal microbial population (Figure 1) [50]. The relatively lower microbial population in the vagina during the gestational period could lead to a greater risk of dysbiosis and abortion. Similarly, in humans, the microbial population in the vagina decreases as duration of the gestational period increases [72,73]. Unlike in humans, the vaginal microbiome of cattle is relatively stable throughout the gestational period [17]. In nonpregnant heifers, Pasteurellaceae spp. and Fusobacterium spp. were abundant in the vagina, whereas pregnant heifers had a greater prevalence of Pasteurella multocida (Table 1) [47].

\subsubsection{Postpartum}

A large variation among individuals was reported in the uterine microbiome of cows without uterine infections during the first month postpartum $[53,54]$. Alpha and beta diversities were not affected by the postpartum day of sampling with the bacterial diversity being 
similar among 10,21, and 35 days postpartum (DPP) in the uterus of cows without uterine inflammation and those with uterine inflammation; however, the uterine microbiome was markedly different between the two groups (Figure 1) [53]. Based on results from a metagenomic analysis of uterine simples collected three times during the first 35 DPP, the uterine microbiome of cows without uterine inflammation was predominantly composed of Porphyromonas, Bacillus, Schlegelella, Paracoccus, and Fusobacterium (Table 1) [53].

Interestingly, the vaginal, and uterine microbiomes of cows without uterine inflammation during the first 50 DPP were similar and were highly enriched with Firmicutes [54]. This finding could be explained by the fact that soon after calving, the cervical lumen is less constricted, resulting in a mixing of the vaginal and uterine milieu with there being movement of these contents throughout the reproductive tract. We hypothesize that in cows without uterine inflammation, the genital microbiome is not contaminated during calving by the external microbiome or at least not affected for an extended period subsequent to parturition. A comparison of the genital microbiome of pregnant cows before calving retrospectively with those that develop endometritis after 21 DPP to those that continue to have an uninfected uterus revealed that genital microbiome pre-calving was similar to the vaginal microbiome of healthy cows that did not develop uterine infections subsequent to 21 DPP [54].

\subsection{Extrinsic Factors}

\subsubsection{Nutrition}

The microbial population of the uterus of dairy cows during the postpartum period was reported to be affected by the nutrient content of the diet, especially the energy content, around the time of calving (Figure 1) [18]. Cows that were fed $80 \%$ of the energy requirement had uterine inflammation, and the predominant species of the uterine microbiome were Bacteroidetes and Fusobacteria (Table 1). A comparison of the uterine microbiome precalving to that post-calving in cows that developed metritis with those that did not contract metritis indicated that cows with metritis had predominantly Bacteroides and Fusobacteria and a lower abundance of Proteobacteria and Tenericutes, which was markedly different from those that did not have metritis [8]. Therefore, nutrition affects the genital microbiome through the modulation of general metabolism and immune functions and therefore affects the occurrence of dysbiosis and genital infections.

\subsubsection{Genital Pathologies}

Interestingly, cows with subclinical endometritis had a similar uterine microbiome compared to cows without uterine inflammation between 10 and 35 DPP; however, cows with clinical endometritis had a microbiome with a different composition compared to the two other groups (Figure 1) [53]. Cows affected with clinical endometritis had a lower bacterial diversity characterized by a greater prevalence of Fusobacterium and Trueperella associated with a lower abundance of Escherichia, Shigella, Lactobacillus, Prevotella, Schlegelella, and Streptococcus compared to cows without uterine inflammation and those with subclinical endometritis (Table 1) [53,54]. This latter group had relatively a greater prevalence of Anaerococcus, Corynebacterium, and Staphylococcus compared to cows with clinical endometritis.

The microbial population of the uterus and the vagina at 7 DPP is associated with the risk of developing clinical endometritis after 21 DPP [54]. The vaginal microbiome at 7 DPP in cows with endometritis is highly enriched with Bacteroides, Helcococcus, and Fusobacterium, unlike cows without uterine inflammation where Firmicutes are the most predominant. Comparisons of the uterine and vaginal microbiomes in these animals indicated that at 7 DPP, the microbial composition was similar between the two compartments, but this similarity was less between 21 and 50 DPP [54]. These findings confirm that the genital microbiome of cows at risk of developing endometritis is not completely established during first month postpartum, unlike in cows without uterine inflammation where the uterine and vaginal microbiomes are well established at day 7 postpartum [54]. 
Metritis, which is indicated by a marked inflammation of the endometrium and myometrium soon after calving and before day 21 postpartum, is characterized by relatively lower abundance of the vaginal microbiome quantities and higher relative abundance of Bacteroides, Porphyromonas, and Fusobacterium (Table 1) [8,55]. Likewise, cows with metritis had a uterine microbiome that was markedly enriched with F. necrophorum, Porphyromonas levii, and Prevotella melaninogenica compared with cows without metritis [56]. E. coli is another interesting bacterium that is detected early postpartum in most of the cows because the presence of this microbe is important for the development of F. necrophorum, leading to metritis, while the latter bacterium is often detected in association with T. pyogenes in the case of endometritis [8,57]. In women with mild or moderate vaginal atrophy, the vaginal microbial population tends to be predominantly invasive pathogens, mainly Streptococcus and Prevotella [74]. Microbiomes in cattle diagnosed with necrotic vulvovaginitis (BNVV), as compared with those not diagnosed with BNVV, are characterized by a relatively microbial diversity and a large abundance of Bacateroidetes [58].

\section{Dysbiosis and Genital Microbiome Disruption}

Bacterial dysbiosis is an inflammatory condition characterized by the presence of polymicrobial populations of commensal microbes in moderate abundance or the complete absence of these commensal microbes. In humans, bacterial vaginosis, a type of dysbiosis, is characterized by the predominance of specific species of strict and facultative anaerobic microbes associated with a lower abundance or complete absence of Lactobacilli and larger microbial population in the vaginal microbiome [72,75]. Results from a study conducted to investigate whether microbes that were predominant in the vagina before mating could be predictive of females that will become pregnant revealed that Histophilus somni, Clostridiaceae 02d06, and Campylobacter were abundant in cows that failed to conceive (Table 1) [17]. Commensal bacteria present in the genital tract, mainly the vagina in females without uterine inflammation, have important functions in the genital tract by suppressing infection by major pathogens by different mechanisms, mainly through the competition effect by the occupation of specific receptors to which pathogenic microbes bind to gain entry into cells and by secreting immune active molecules such as lactic acid [11]. Interestingly, the absence or decreased abundance of Lactobacilli in the genital tract of pregnant women was associated with a lower vaginal $\mathrm{pH}$, leading to overgrowth of more pathogenic microbes $[7,76]$. The inflammatory reaction, therefore, is induced, and interleukin 8 (IL-8) is secreted in large quantities, leading to abortion or premature parturition [76]. In pregnant cows, the size of the population of $S$. aureus was associated with the risk of abortion, while this pathogen was rarely isolated from cows that had a typical length of gestation [51]. T. pyogenes is another major pathogen associated with abortion during the last half of gestation [52]. While Fusobacteria and Bacteroidetes are common flora of the genital tract in cows with or without genital tract inflammation, preventing the overgrowth of these bacteria is important for preventing reproductive tract infections [8]. Intravaginal antibiotic treatment affects the genital microbiome, leading to dysbiosis. Bitches administrated antibiotics intravaginally during estrus were less likely to attract males when in estrus compared with females not treated with antibiotics (Figure 1) [77]. The changes in the sexual behavior would be the result of changes in the microbial diversity and the semiochemical signal emitted by the modified microbiome because of the antibiotic treatment.

\section{Genital Microbial Population as Probiotic Treatment for Dysbiosis}

Treating reproductive diseases in cattle is a challenge for veterinarians and farmers. For example, antibiotic treatment of metritis results in only 67 to $77 \%$ of the cases recovering from clinical symptoms, yet fertility continues to be compromised [78]. Modulating the genital microbiome using probiotics is becoming an effective strategy in humans $[21,79,80]$. The administration of lactic acid bacteria intravaginally resulted in modification of the uterine microbiome [81] while intravaginal administration of L. plantarum P17630 prevented 
recurrent vulvovaginal candidiasis [21]. Likewise, L. crispatus administrated intravaginally was effective in the management of recurrent urinary tract infections [79].

In cattle, intravaginal treatment with a mixture of lactic acid bacteria, L. rhamnosus CECT 278, Pediococcus acidilactici CECT 5,915, and L. reuteri DSM 20016, three weeks before calving resulted in decreased metritis prevalence by $58 \%$ [80]. The probiotic treatment using lactic acid bacteria modulates the inflammatory reaction by downregulating the relative abundance of the $L$-selectin mRNA transcript, which encodes for this protein. The Lselectin protein has been implicated in the neutrophil infiltration into the infected tissue and expression of the tumor necrosis factor receptor (TNF-R) gene that modulates degranulation and phagocytic processes $[80,82,83]$. This reduction in neutrophil activity could be the result of reduced pathogenic bacteria in the genital tract due to a competitive effect of lactic acid bacteria or by coaggregation with more pathogenic microbes reducing the adhesion of these pathogens to specific receptors on the cell surface $[80,84]$. Results from in vivo and ex vitro studies revealed that the association of L. rhamnosus, Pediococcus acidilactici, and $L$. reuteri resulted in a marked reduction of the inflammatory profile of endometrial epithelial cells when E. coli was administered or included in the culture medium [85]. Likewise, the growth of $S$. aureus, one of the major pathogens implicated in postpartum infections in dairy cattle, was inhibited in vitro under treatment with L. gasseri CRL1421 and CRL1412 [86].

\section{Conclusions}

The genital microbiota represents an opportunistic field of study in the realm of cattle fertility when considering the microbiome is an essential immunological barrier against pathogens and for pheromone production. Specific questions that can be addressed are the functions of specific bacteria taxa involved in physiological uterine involution in postpartum cows. With dysbiosis, uterine disease can occur; thus, modulating the vaginal microbiome may be an effective alternative to antibiotic therapies. Therefore, intravaginal inoculation of cattle at risk of infection represents possible probiotic management of genital postpartum uterine infections.

Author Contributions: M.A. and A.C. state that all authors contributed equally to writing and proof editing of the paper in its final form and approved it for submission. M.A. and A.C. state that the manuscript, including related figures, has not been previously published and that the manuscript is not under consideration elsewhere. All authors have read and agreed to the published version of the manuscript.

Funding: This research did not receive any specific grant from funding agencies in the public, commercial, or not-for-profit sectors. Publication fees were provided by the Integrative Mammalian Research Center (C2), Ross University School of Veterinary Medicine.

Institutional Review Board Statement: Not applicable.

Informed Consent Statement: Not applicable.

Data Availability Statement: Not applicable.

Conflicts of Interest: None of the authors of this paper has a financial or personal relationship with other people or organizations that could inappropriately influence or bias the content of the paper.

\section{References}

1. The Human Microbiome Project Consortium. Structure, function and diversity of the healthy human microbiome. Nature 2012, 486, 207-214. [CrossRef] [PubMed]

2. Jeon, S.J.; Neto, A.V.; Gobikrushanth, M.; Daetz, R.; Mingoti, R.D.; Parize, A.C.B.; de Freitas, S.L.; da Costa, A.N.L.; Bicalho, R.C.; Lima, S.; et al. Uterine Microbiota Progression from Calving until Establishment of Metritis in Dairy Cows. Appl. Environ. Microbiol. 2015, 81, 6324-6332. [CrossRef] [PubMed]

3. Lacroix, G.; Gouyer, V.; Gottrand, F.; Desseyn, J.-L. The Cervicovaginal Mucus Barrier. Int. J. Mol. Sci. 2020, 21, 8266. [CrossRef] [PubMed]

4. Sheldon, I.; Dobson, H. Postpartum uterine health in cattle. Anim. Reprod. Sci. 2004, 82, 295-306. [CrossRef] [PubMed]

5. Santos, T.M.A.; Gilbert, R.O.; Bicalho, R.C. Metagenomic analysis of the uterine bacterial microbiota in healthy and metritic postpartum dairy cows. J. Dairy Sci. 2011, 94, 291-302. [CrossRef] 
6. $\quad$ Rodrigues, N.; Kästle, J.; Coutinho, T.J.D.; Amorim, A.T.; Campos, G.; Santos, V.; Marques, L.; Timenetsky, J.; de Farias, S. Qualitative analysis of the vaginal microbiota of healthy cattle and cattle with genital-tract disease. Genet. Mol. Res. 2015, 14, 6518-6528. [CrossRef]

7. Miller, E.A.; Beasley, D.E.; Dunn, R.R.; Archie, E.A. Lactobacilli Dominance and Vaginal pH: Why Is the Human Vaginal Microbiome Unique? Front. Microbiol. 2016, 7, 1936. [CrossRef]

8. Galvão, K.N.; Bicalho, R.C.; Jeon, S.J. Symposium review: The uterine microbiome associated with the development of uterine disease in dairy cows. J. Dairy Sci. 2019, 102, 11786-11797. [CrossRef]

9. Tang, G.; Kitten, T.; Munro, C.L.; Wellman, G.C.; Mintz, K.P. EmaA, a Potential Virulence Determinant of Aggregatibacter actinomycetemcomitans in Infective Endocarditis. Infect. Immun. 2008, 76, 2316-2324. [CrossRef]

10. Swartz, J.D.; Lachman, M.; Westveer, K.; O’Neill, T.; Geary, T.; Kott, R.W.; Berardinelli, J.G.; Hatfield, P.G.; Thomson, J.M.; Roberts, A.; et al. Characterization of the Vaginal Microbiota of Ewes and Cows Reveals a Unique Microbiota with Low Levels of Lactobacilli and Near-Neutral pH. Front. Vet. Sci. 2014, 1, 19. [CrossRef]

11. Tachedjian, G.; Aldunate, M.; Bradshaw, C.S.; Cone, R.A. The role of lactic acid production by probiotic Lactobacillus species in vaginal health. Res. Microbiol. 2017, 168, 782-792. [CrossRef] [PubMed]

12. Romero, R.; Hassan, S.S.; Gajer, P.; Tarca, A.L.; Fadrosh, D.W.; Nikita, L.; Galuppi, M.; Lamont, R.F.; Chaemsaithong, P.; Miranda, J.; et al. The composition and stability of the vaginal microbiota of normal pregnant women is different from that of non-pregnant women. Microbiome 2014, 2, 4. [CrossRef] [PubMed]

13. Srinivasan, M.; Adnane, M.; Archunan, G. Significance of cervico-vaginal microbes in bovine reproduction and pheromone production-A hypothetical review. Res. Vet. Sci. 2021, 135, 66-71. [CrossRef] [PubMed]

14. Jeon, S.J.; Cunha, F.; Neto, A.V.; Bicalho, R.C.; Lima, S.; Bicalho, M.L.; Galvão, K.N. Blood as a route of transmission of uterine pathogens from the gut to the uterus in cows. Microbiome 2017, 5, 109. [CrossRef]

15. Lin, Y.; Yang, H.; Ahmad, M.J.; Yang, Y.; Yang, W.; Riaz, H.; Abulaiti, A.; Zhang, S.; Yang, L.; Hua, G. Postpartum Uterine Involution and Embryonic Development Pattern in Chinese Holstein Dairy Cows. Front. Vet. Sci. 2020, 7, 604729. [CrossRef]

16. Barba, M.; Martínez-Boví, R.; Quereda, J.; Mocé, M.; Plaza-Dávila, M.; Jiménez-Trigos, E.; Gómez-Martín, Á.; González-Torres, P.; Carbonetto, B.; García-Roselló, E. Vaginal Microbiota Is Stable throughout the Estrous Cycle in Arabian Maress. Animals 2020, 10, 2020. [CrossRef]

17. Deng, F.; McClure, M.; Rorie, R.; Wang, X.; Chai, J.; Wei, X.; Lai, S.; Zhao, J. The vaginal and fecal microbiomes are related to pregnancy status in beef heifers. J. Anim. Sci. Biotechnol. 2019, 10, 92. [CrossRef]

18. Esposito, G.; Raffrenato, E.; Lukamba, S.D.; Adnane, M.; Irons, P.C.; Cormican, P.; Tasara, T.; Chapwanya, A. Characterization of metabolic and inflammatory profiles of transition dairy cows fed an energy-restricted diet. J. Anim. Sci. 2020, 98, 98. [CrossRef]

19. Mahalingam, S.; Dharumadurai, D.; Archunan, G. Vaginal microbiome analysis of buffalo (Bubalus bubalis) during estrous cycle using high-throughput amplicon sequence of $16 \mathrm{~S}$ rRNA gene. Symbiosis 2019, 78, 97-106. [CrossRef]

20. Castro, J.; Cerca, N. BV and non-BV associated Gardnerella vaginalis establish similar synergistic interactions with other BV-associated microorganisms in dual-species biofilms. Anaerobe 2015, 36, 56-59. [CrossRef]

21. De Seta, F.; Parazzini, F.; de Leo, R.; Banco, R.; Maso, G.; de Santo, D.; Sartore, A.; Stabile, G.; Inglese, S.; Tonon, M.; et al Lactobacillus plantarum P17630 for preventing Candida vaginitis recurrence: A retrospective comparative study. Eur. J. Obstet. Gynecol. Reprod. Biol. 2014, 182, 136-139. [CrossRef] [PubMed]

22. Chen, S.-Y.; Deng, F.; Zhang, M.; Jia, X.; Lai, A.S.-J. Characterization of vaginal microbiota associated with pregnancy outcomes of artificial insemination in dairy cows. J. Microbiol. Biotechnol. 2020, 30, 804-810. [CrossRef] [PubMed]

23. Clark, W.A.; Stevenson, W.G. Bacterial Flow of Uterus. Can. J. Comp. Med. Vet. Sci. 1949, 13, 92-93. [PubMed]

24. Parkinson, T.J. Infertility and subfertility in the cow: Structural and functional abnormalities, management deficiencies and non-specific infections. In Veterinary Reproduction and Obstetrics; Noakes, D.E., Parkinson, T., England, G.C.W., Eds.; Saunders Elsevier: Shanghai, China, 2009; pp. 391-475.

25. Sheldon, I.M.; Noakes, D.E.; Rycroft, A.; Dobson, H. Acute phase protein responses to uterine bacterial contamination in caftle after calving. Vet. Rec. 2001, 148, 172-175. [CrossRef] [PubMed]

26. Karstrup, C.C.; Klitgaard, K.; Jensen, T.K.; Agerholm, J.S.; Pedersen, H.G. Presence of bacteria in the endometrium and placentomes of pregnant cows. Theriogenology 2017, 99, 41-47. [CrossRef]

27. Singh, J.; Behal, A.; Singla, N.; Joshi, A.; Birbian, N.; Singh, S.; Bali, V.; Batra, N. Metagenomics: Concept, methodology, ecological inference and recent advances. Biotechnol. J. 2009, 4, 480-494. [CrossRef]

28. Dominguez-Bello, M.G.; Costello, E.K.; Contreras, M.; Magris, M.; Hidalgo, G.; Fierer, N.; Knight, R. Delivery mode shapes the acquisition and structure of the initial microbiota across multiple body habitats in newborns. Proc. Natl. Acad. Sci. USA 2010, 107, 11971-11975. [CrossRef]

29. Chee, W.J.Y.; Chew, S.Y.; Than, L.T.L. Vaginal microbiota and the potential of Lactobacillus derivatives in maintaining vaginal health. Microb. Cell Fact. 2020, 19, 203. [CrossRef]

30. O'Hanlon, D.E.; Moench, T.R.; Cone, R.A. Vaginal pH and Microbicidal Lactic Acid When Lactobacilli Dominate the Microbiota. PLoS ONE 2013, 8, e80074. [CrossRef]

31. Alakomi, H.-L.; Skytta, E.; Saarela, M.; Mattila-Sandholm, T.; Latva-Kala, K.; Helander, I.M. Lactic Acid Permeabilizes GramNegative Bacteria by Disrupting the Outer Membrane. Appl. Environ. Microbiol. 2000, 66, 2001-2005. [CrossRef] 
32. Nardini, P.; Palomino, R.A.N.; Parolin, C.; Laghi, L.; Foschi, C.; Cevenini, R.; Vitali, B.; Marangoni, A. Lactobacillus crispatus inhibits the infectivity of Chlamydia trachomatis elementary bodies, in vitro study. Sci. Rep. 2016, 6, 29024. [CrossRef] [PubMed]

33. Graver, M.A.; Wade, J.J. The role of acidification in the inhibition of Neisseria gonorrhoeae by vaginal lactobacilli during anaerobic growth. Ann. Clin. Microbiol. Antimicrob. 2011, 10, 8. [CrossRef] [PubMed]

34. Valore, E.V.; Park, C.H.; Igreti, S.L.; Ganz, T. Antimicrobial components of vaginal fluid. Am. J. Obstet. Gynecol. 2002, 187, 561-568. [CrossRef] [PubMed]

35. Taha, T.E.; Hoover, D.R.; Dallabetta, G.A.; Kumwenda, N.I.; Mtimavalye, L.A.R.; Yang, L.-P.; Liomba, G.N.; Broadhead, R.L.; Chiphangwi, J.D.; Miotti, P.G. Bacterial vaginosis and disturbances of vaginal flora: Association with increased acquisition of HIV. AIDS 1998, 12, 1699-1706. [CrossRef]

36. Hoang, T.; Toler, E.; Delong, K.; Mafunda, N.A.; Bloom, S.M.; Zierden, H.C.; Moench, T.R.; Coleman, J.S.; Hanes, J.; Kwon, D.S.; et al. The cervicovaginal mucus barrier to HIV-1 is diminished in bacterial vaginosis. PLoS Pathog. 2020, 16, e1008236. [CrossRef]

37. Aldunate, M.; Tyssen, D.; Johnson, A.; Zakir, T.; Sonza, S.; Moench, T.; Cone, R.; Tachedjian, G. Vaginal concentrations of lactic acid potently inactivate HIV. J. Antimicrob. Chemother. 2013, 68, 2015-2025. [CrossRef]

38. Archunan, G.; Rajanarayanan, S.; Karthikeyan, K. Cattle Pheromones. In Neurobiology of Chemical Communication; Mucignat-Caretta, C., Ed.; Frontiers in Neuroscience; CRC Press/Taylor \& Francis LLC.: Boca Raton, FL, USA, 2014.

39. Archunan, G. Reproductive enhancement in buffalo: Looking at urinary pheromones and hormones. Iran. J. Vet. Res. 2020, 21, 163-171.

40. LeClaire, S.; Nielsen, J.F.; Drea, C.M. Bacterial communities in meerkat anal scent secretions vary with host sex, age, and group membership. Behav. Ecol. 2014, 25, 996-1004. [CrossRef]

41. Sankar, R.; Archunan, G. Flehmen response in bull: Role of vaginal mucus and other body fluids of bovine with special reference to estrus. Behav. Process. 2004, 67, 81-86. [CrossRef]

42. LeClaire, S.; Jacob, S.; Greene, L.K.; Dubay, G.R.; Drea, C.M. Social odours covary with bacterial community in the anal secretions of wild meerkats. Sci. Rep. 2017, 7, 3240. [CrossRef]

43. Mazmanian, S.K.; Liu, C.H.; Tzianabos, A.O.; Kasper, D.L. An Immunomodulatory Molecule of Symbiotic Bacteria Directs Maturation of the Host Immune System. Cell 2005, 122, 107-118. [CrossRef] [PubMed]

44. Wexler, H.M. Bacteroides: The Good, the Bad, and the Nitty-Gritty. Clin. Microbiol. Rev. 2007, 20, 593-621. [CrossRef] [PubMed]

45. Kraipowich, N.R.; Morris, D.L.; Thompson, G.L.; Mason, G.L. Bovine abortions associated with Bacteroides fragilis fetal infection. J. Vet. Diagn. Investig. 2000, 12, 369-371. [CrossRef]

46. Laguardia-Nascimento, M.; Branco, K.M.G.R.; Gasparini, M.R.; Giannattasio-Ferraz, S.; Leite, L.R.; Araújo, F.M.G.; Salim, A.C.D.M.; Nicoli, J.R.; de Oliveira, G.C.; Barbosa-Stancioli, E. Vaginal Microbiome Characterization of Nellore Cattle Using Metagenomic Analysis. PLoS ONE 2015, 10, e0143294. [CrossRef]

47. Messman, R.; Contreras-Correa, Z.E.; Paz, H.A.; Perry, G.; Lemley, C.O. Vaginal bacterial community composition and concentrations of estradiol at the time of artificial insemination in Brangus heifers. J. Anim. Sci. 2020, 98, 98. [CrossRef] [PubMed]

48. Quadros, D.L.; Zanella, R.; Bondan, C.; Zanella, G.C.; Facioli, F.L.; da Silva, A.N.; Zanella, E.L. Study of vaginal microbiota of Holstein cows submitted to an estrus synchronization protocol with the use of intravaginal progesterone device. Res. Vet. Sci. 2020, 131, 1-6. [CrossRef] [PubMed]

49. Giannattasio-Ferraz, S.; Laguardia-Nascimento, M.; Gasparini, M.R.; Leite, L.R.; Araujo, F.M.G.; de Matos Salim, A.C.; de Oliveira, A.P.; Nicoli, J.R.; de Oliveira, G.C.; da Fonseca, F.G.; et al. A common vaginal microbiota composition among breeds of Bos taurus indicus (Gyr and Nellore). Braz. J. Microbiol. 2019, 50, 1115-1124. [CrossRef]

50. Otero, C.; de Ruiz, C.S.; Ibañez, R.; Wilde, O.; Holgado, A.D.R.; Nader-Macias, M. Lactobacilli and Enterococci Isolated from the Bovine Vagina during the Estrous cycle. Anaerobe 1999, 5, 305-307. [CrossRef]

51. Galvão, K.N. Postpartum uterine diseases in dairy cows. Anim. Reprod. 2012, 9, 290-296.

52. Anderson, M.L. Infectious causes of bovine abortion during mid- to late-gestation. Theriogenology 2007, 68, 474-486. [CrossRef]

53. Pascottini, O.B.; van Schyndel, S.J.; Spricigo, J.F.W.; Rousseau, J.; Weese, J.S.; Leblanc, S.J. Dynamics of uterine microbiota in postpartum dairy cows with clinical or subclinical endometritis. Sci. Rep. 2020, 10, 12353. [CrossRef] [PubMed]

54. Miranda-CasoLuengo, R.; Lu, J.; Williams, E.J.; Miranda-CasoLuengo, A.A.; Carrington, S.D.; Evans, A.C.O.; Meijer, W.G. Delayed differentiation of vaginal and uterine microbiomes in dairy cows developing postpartum endometritis. PLoS ONE 2019, 14, e0200974. [CrossRef] [PubMed]

55. Sheldon, I.M.; Williams, E.; Miller, A.N.; Nash, D.M.; Herath, S. Uterine diseases in cattle after parturition. Vet. J. 2008, 176 115-121. [CrossRef] [PubMed]

56. Cunha, F.; Jeon, S.J.; Daetz, R.; Neto, A.V.; Laporta, J.; Jeong, K.C.; Barbet, A.F.; Risco, C.A.; Galvão, K.N. Quantifying known and emerging uterine pathogens, and evaluating their association with metritis and fever in dairy cows. Theriogenology 2018, 114, 25-33. [CrossRef] [PubMed]

57. Bicalho, M.; Machado, V.; Oikonomou, G.; Gilbert, R.; Bicalho, R. Association between virulence factors of Escherichia coli, Fusobacterium necrophorum, and Arcanobacterium pyogenes and uterine diseases of dairy cows. Vet. Microbiol. 2012, 157, 125-131. [CrossRef] [PubMed]

58. Shpigel, N.; Adler-Ashkenazy, L.; Scheinin, S.; Goshen, T.; Arazi, A.; Pasternak, Z.; Gottlieb, Y. Characterization and identification of microbial communities in bovine necrotic vulvovaginitis. Vet. J. 2017, 219, 34-39. [CrossRef] 
59. Moore, S.; Ericsson, A.C.; Poock, S.E.; Melendez, P.; Lucy, M.C. Hot topic: 16 S rRNA gene sequencing reveals the microbiome of the virgin and pregnant bovine uterus. J. Dairy Sci. 2017, 100, 4953-4960. [CrossRef]

60. Sheldon, I.M.; Cronin, J.G.; Bromfield, J.J. Tolerance and Innate Immunity Shape the Development of Postpartum Uterine Disease and the Impact of Endometritis in Dairy Cattle. Annu. Rev. Anim. Biosci. 2019, 7, 361-384. [CrossRef]

61. van der Burgt, G.; Clark, W.; Knight, R. Cattle fertility problems and Histophilus somni. Vet. Rec. 2007, 160, 600. [CrossRef]

62. Nicholas, R.; Ayling, R.; McAuliffe, L. Mycoplasma Diseases of Ruminants: Disease, Diagnosis and Control; CAB International: Oxfordshire, UK, 2008.

63. Kovachev, S. Defence factors of vaginal lactobacilli. Crit. Rev. Microbiol. 2018, 44, 31-39. [CrossRef]

64. Ulrich, D.; Edwards, S.L.; Letouzey, V.; Su, K.; White, J.F.; Rosamilia, A.; Gargett, C.E.; Werkmeister, J.A. Regional Variation in Tissue Composition and Biomechanical Properties of Postmenopausal Ovine and Human Vagina. PLoS ONE 2014, 9, e104972. [CrossRef] [PubMed]

65. Sheldon, I.M.; Noakes, D.E.; Rycroft, A.N.; Pfeiffer, D.U.; Dobson, H. Influence of uterine bacterial contamination after parturition on ovarian dominant follicle selection and follicle growth and function in cattle. Reproduction 2002, 123, 837-845. [CrossRef] [PubMed]

66. Williams, E.; Fischer, D.; Noakes, D.; England, G.; Rycroft, A.; Dobson, H.; Sheldon, I. The relationship between uterine pathogen growth density and ovarian function in the postpartum dairy cow. Theriogenology 2007, 68, 549-559. [CrossRef] [PubMed]

67. Otero, C.; Saavedra, L.; de Ruiz, C.S.; Wilde, O.; Holgado, A.; Nader-Macias, M. Vaginal bacterial microflora modifications during the growth of healthy cows. Lett. Appl. Microbiol. 2000, 31, 251-254. [CrossRef]

68. Sawyer, G.J. Observations on the bacterial population of the os cervix of the ewe before and after embryo death. Aust. Vet. J. 1977, 53, 542-544. [CrossRef]

69. Manes, J.; Fiorentino, M.A.; Kaiser, G.; Hozbor, F.; Alberio, R.; Sanchez, E.; Paolicchi, F. Changes in the aerobic vaginal flora after treatment with different intravaginal devices in ewes. Small Rumin. Res. 2010, 94, 201-204. [CrossRef]

70. Gorodeski, G.I.; Hopfer, U.; Liu, C.C.; Margles, E. Estrogen Acidifies Vaginal pH by Up-Regulation of Proton Secretion via the Apical Membrane of Vaginal-Ectocervical Epithelial Cells. Endocrinology 2005, 146, 816-824. [CrossRef]

71. Perry, G.; Perry, B. Effect of preovulatory concentrations of estradiol and initiation of standing estrus on uterine $\mathrm{pH}$ in beef cows. Domest. Anim. Endocrinol. 2008, 34, 333-338. [CrossRef]

72. Gajer, P.; Brotman, R.M.; Bai, G.; Sakamoto, J.; Schütte, U.M.E.; Zhong, X.; Koenig, S.S.K.; Fu, L.; Ma, Z.; Zhou, X.; et al. Temporal Dynamics of the Human Vaginal Microbiota. Sci. Transl. Med. 2012, 4, 132ra52. [CrossRef]

73. Aagaard, K.; Riehle, K.; Ma, J.; Segata, N.; Mistretta, T.-A.; Coarfa, C.; Raza, S.; Rosenbaum, S.; van der Veyver, I.; Milosavljevic, A.; et al. A Metagenomic Approach to Characterization of the Vaginal Microbiome Signature in Pregnancy. PLoS ONE 2012, 7, e36466. [CrossRef]

74. Brotman, R.M.; Shardell, M.D.; Gajer, P.; Fadrosh, D.; Chang, K.; Silver, M.; Viscidi, R.P.; Burke, A.E.; Ravel, J.; Gravitt, P.E. Association between the vaginal microbiota, menopause status, and signs of vulvovaginal atrophy. Menopause 2014, 21, 450-458. [CrossRef] [PubMed]

75. Smith, S.B.; Ravel, J. The vaginal microbiota, host defence and reproductive physiology. J. Physiol. 2017, 595, 451-463. [CrossRef] [PubMed]

76. Sakai, M.; Ishiyama, A.; Tabata, M.; Sasaki, Y.; Yoneda, S.; Shiozaki, A.; Saito, S. Relationship between Cervical Mucus Interleukin-8 Concentrations and Vaginal Bacteria in Pregnancy. Am. J. Reprod. Immunol. 2004, 52, 106-112. [CrossRef]

77. Dzięcioł, M.; Niżański, W.; Stańczyk, E.; Kozdrowski, R.; Najder-Kozdrowska, L.; Twardoń, J. The influence of antibiotic treatment of bitches in oestrus on their attractiveness to males during mating. Pol. J. Vet. Sci. 2013, 16, 509-516. [CrossRef] [PubMed]

78. LeBlanc, S.J. Postpartum uterine disease and dairy herd reproductive performance: A review. Vet. J. 2008, 176, 102-114. [CrossRef]

79. Stapleton, A.E.; Au-Yeung, M.; Hooton, T.M.; Fredricks, D.N.; Roberts, P.L.; Czaja, C.A.; Yarova-Yarovaya, Y.; Fiedler, T.; Cox, M.; Stamm, W.E. Randomized, placebo-controlled phase 2 trial of a Lactobacillus crispatus probiotic given intravaginally for prevention of recurrent urinary tract infection. Clin. Infect. Dis. 2011, 52, 1212-1217. [CrossRef]

80. Genís, S.; Cerri, R.L.A.; Bach, Â.; Silper, B.F.; Baylão, M.; Denis-Robichaud, J.; Arís, A. Pre-calving Intravaginal Administration of Lactic Acid Bacteria Reduces Metritis Prevalence and Regulates Blood Neutrophil Gene Expression After Calving in Dairy Cattle. Front. Vet. Sci. 2018, 5, 135. [CrossRef]

81. Genís, S.; Bach, À.; Arís, A. Effects of intravaginal lactic acid bacteria on bovine endometrium: Implications in uterine health. Vet. Microbiol. 2017, 204, 174-179. [CrossRef]

82. Abbas, A.K.; Lichtman, A.H.; Pillai, S. Cellular and Molecular Immunology; Elsevier/Saunders: Philadelphia, PA, USA, 2012.

83. Sheldon, I.M. The postpartum uterus. Vet. Clin. N. Am. Food Anim. Pract. 2004, 20, 569-591. [CrossRef]

84. Sengupta, R.; Altermann, E.; Anderson, R.; McNabb, W.; Moughan, P.J.; Roy, N.C. The Role of Cell Surface Architecture of Lactobacilli in Host-Microbe Interactions in the Gastrointestinal Tract. Mediat. Inflamm. 2013, 2013, 237921. [CrossRef]

85. Genís, S.; Sánchez-Chardi, A.; Bach, À.; Fàbregas, F.; Arís, A. A combination of lactic acid bacteria regulates Escherichia coli infection and inflammation of the bovine endometrium. J. Dairy Sci. 2017, 100, 479-492. [CrossRef] [PubMed]

86. Otero, M.C.; Nader-Macias, M.E.F. Inhibition of Staphylococcusaureus by $\mathrm{H}_{2} \mathrm{O}_{2}$-producing Lactobacillus gasseri isolated from the vaginal tract of cattle. Anim. Reprod. Sci. 2006, 96, 35-46. [CrossRef] [PubMed] 